\title{
DEMOLITION IN REGENERATION MEGAPROJECTS: THE CASE OF WIEN HAUPTBAHNHOF
}

\author{
Piotr Kosmowski \\ Institute of Urban Geography and Tourism Studies \\ Faculty of Geographical Sciences \\ University of Łódź \\ Kopcińskiego 31, 90-142 Łódź: Poland \\ e-mail: piotr.kosmowski@geo.uni.lodz.pl
}

\begin{abstract}
Regeneration of centrally located city areas has been increasingly more often undertaken as a regeneration megaproject exercise. In European cities there are vast post-railway areas, which, if transformed, can produce morphological and functional changes. Against this background, investigating demolition as part of transformation of the existing spatial and functional structures is an interesting option. Transformations proposed for the downtown area of Vienna previously occupied by the Wien Südbahnhof railway station include the reconstruction of 109 ha formerly used exclusively by railway sector operators. The research problem boils down to the question: what was the course of demolition of the area covered by modernisation works carried out as a megaproject and how has it transformed space organisation on the spot? The paper analyses the sequence of urban renewal initiated in Vienna in the area adjacent to the new Wien Hauptbahnhof railway station and identifies the outcomes of the process. Regeneration project triggered the decision to completely demolish all elements of the existing railway infrastructure and to reconstruct it anew on a much smaller area. Recuperated post-railway land was made available to housing developers, as well as to service facilities and leisure projects, which expand central area of the city.
\end{abstract}

\section{Key words}

megaproject • demolition - regeneration - railway areas - Wien Hauptbahnhof - Wien Südbahnhof

\section{Introduction}

Areas used for railway-related functions in city centres are in many ways valuable plots which may help impede urban sprawl. Due to the size of such territories, as well as the scope and cost entailed in their transformation, in many cities across the world reconstruction of post-railway areas is undertaken within the framework of regeneration megaprojects. The term describes planned, complex, lengthy and costly (usually with the budget exceeding USD 1bn) investment that changes the image of big urban 


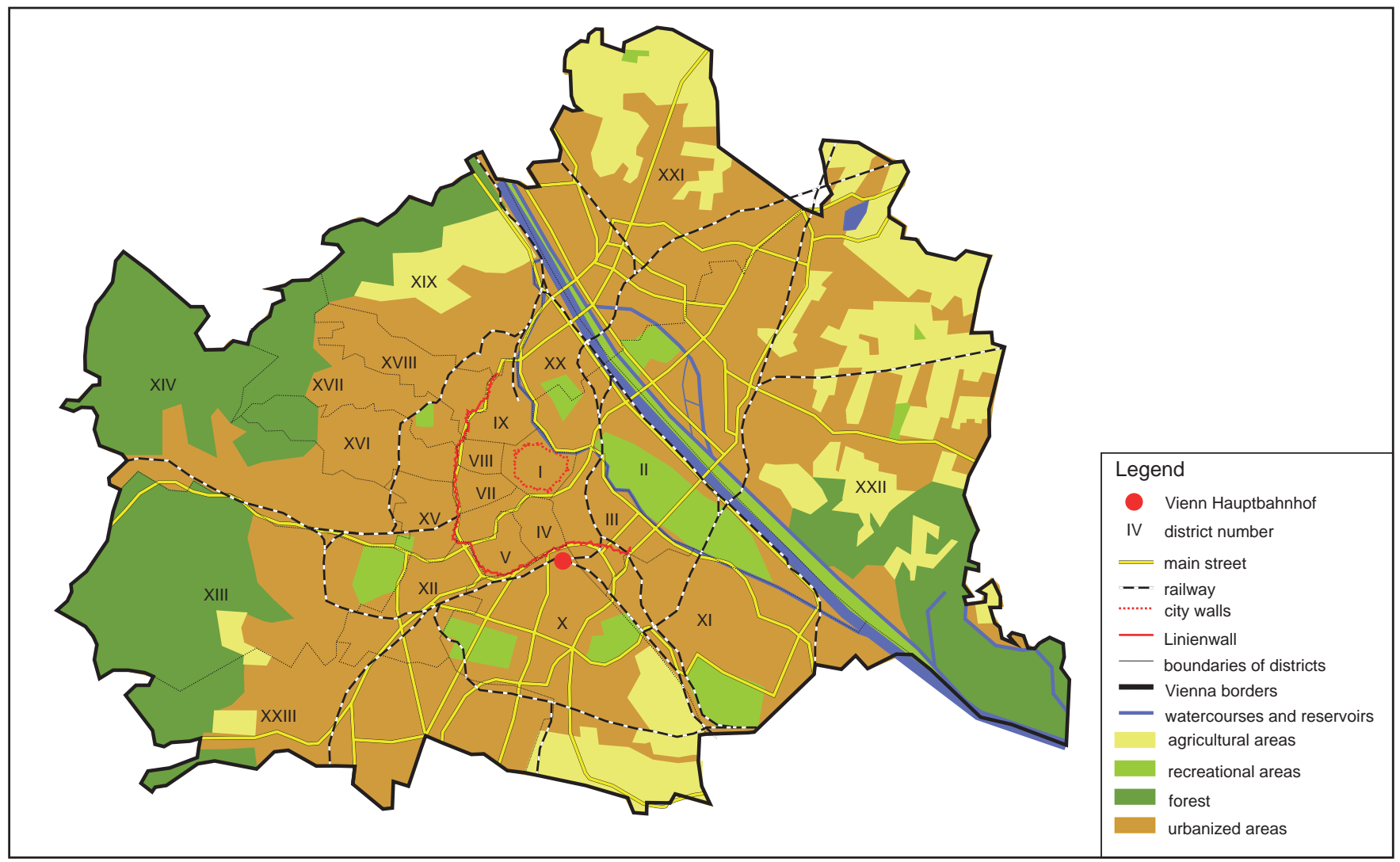


areas (Flyvbjerg 2014). Megaprojects create new areas, which introduce morphological and functional structures previously absent in these locations. In railway or post-railway areas, regeneration megaprojects often include multidimensional demolition. Some researchers (e.g. Ahlfeldt 2012) call these projects hybrids of strategic urban planning strategies and transport infrastructure policies.

Currently, there are some regeneration megaprojects carried out in European cities, which territorially cover areas that used to be (and still are) utilised by the railways (e.g. Stuttgart 21 in Stuttgart, New City Centre in Lodz or King's Cross in London). This group also includes the construction of a new Central Railway Station in Vienna (hereinafter Wien Hauptbahnof). The project with the implementation timetable running from 2007 to 2019 is intended to functionally and spatially restructure 109 ha (ca. 2.6\% of Vienna's area) in the downtown of Vienna at the borders of four districts $(3,4,5$, and 10) incorporated into the administrative borders of the city in the second half of the 19th century when they neighboured the second line of fortifications around the Austrian capital that had been there since the early 18th century (Fig. 1).

The new idea of space organisation and development in this part of the city started with radical moves as all the previously existing buildings with a variety of functions and railway infrastructure used by Wien Südbahnhof railway station and its facilities were demolished in an organised way. We call it planned demolition, that is, damaging and pulling down the existing material structures to clear the area, eliminate facilities and installations to ensure smooth implementation of a new functional programme and a new organisation of space. Research question in these studies focused on the examination of demolition of post-railway areas covered by the megaproject in Vienna and identification of morphological and functional qualities of the new zone created in the city centre as a result of its implementation.
The nature of regeneration project, which includes demolition of the entire transformed area, is thus important for our considerations. In order to solve the research problem, we conducted a comparative analysis of morphological and functional structure of the area in two periods: 2007-2015 and 20152023. Studies were conducted at two levels: we examined documents that have been made available by project executors (Austrian State/National Railways - Österreichische Bundesbahnen - ÖBB and urban authorities) and retrospective documents (strategies and Masterplans) identified in the course of desk studies in Vienna's museums (Wien Museum - Römermuseum, Palace Schönbrunn); we also conducted in situ field studies in August 2015. The latter which included an analysis of morphological and functional structure, focused on the inventories of parts of the city to validate the assumptions of development projects, photographic documentation that was later used in physiognomic analysis. On top of that, we identified the rhythm of the use of space in the area covered by the study by registering pedestrian schemes and accessibility of individual parts of the area. These studies were carried out using the ArcMap 10.2.2. software with its Network Analyst extension.

\section{Demolition and regeneration, megaprojects in the light of subject-matter literature}

Regeneration megaprojects are often used in spatial and functional transformations of vast railway and post-railway areas in cities, where intervention is needed to adjust these areas to the needs and expectations of their contemporary users: owners of railway infrastructure, rail freight forwarders and agents, city authorities, local community, potential new users, as well as owners and users of the adjacent areas (Trip 2008; Novy \& Peters 2012; Kostrzewski 2014; Foljanty 2016). Being complex and multistage planning and implementation undertakings, megaprojects entail huge financial outlays, 
cooperation of a number of investors but, first and foremost, the integration of activities distributed in time and usually running for several years. In literature (Orueta \& Feinstein 2008) the term 'megaproject' is used to describe two types of regeneration effort. The first one, the so called 'flagship project' where the goal of regeneration transformations is to develop a single structure, usually of substantial size, intended as a key role player in the new formula of the functional programme for the area (e.g., a museum). The most often quoted example of this type is the Gugenheim Museum in Bilbao and its importance for the regeneration of port area in the city. The second type of a megaproject distinguished in the studies is a regeneration of a big part of the city experiencing complex functional and spatial changes (e.g., Hamnett \& Shoval 2003; Orueta \& Feinstein 2008). Megaprojects of this type must meet certain criteria. Flyvbjerg (2014) mentions, inter alia, large scale of undertaken activities, costs exceeding USD 1bn, complexity of the undertaking, long-term design and build works, involvement of many public and private actors and impact upon millions of people. Lorens (2006) adds on project complexity, substantial area of the city covered with the project, integrated execution of planned operations and the presence of one 'leading' project manager.

The transformation project of railway and post-railway areas carried out in Vienna meets all the above mentioned criteria hence we may regard it as a proper case study to investigate the coexistence of demolition in regeneration that takes place within the framework of a megaproject. According to data published by city authorities over the time when field studies were conducted (2015), the construction of the new railway station alone amounted to EUR $1 \mathrm{bn}$.

Definitions of regeneration proposed in literature (e.g., Kaczmarek 2001, 2015; Lorens 2010; Parysek 2015) focus on city renewal, on multidimensional aspects of the process but they overlook relationships between the parallel processes of demolition and regeneration. City demolition (after Kaczmarek 2017: 12) should be understood as actions that "enable the introduction of revolutionary morphological, social, cultural and economic changes in the organization of the problem area". Subject-matter literature addressing the relationship between demolition and regeneration shows evolving relations between the two processes in various stages of their coexistence in cities. Carmon (1999) highlights the first generation approach to regeneration, which she calls bulldozer regeneration, covering the interventions carried out between the 1930s until the 1960s. In this approach, demolition was reduced to the pulling down of structures as just a fraction of the process featuring in any regeneration megaproject.

It is obvious that railway areas had undergone transformations since the first railway connection was built for regular passenger service (in the UK Stockton-Darlington route in 1825). That, however, is justified by almost continuous technical improvements of this mode of transport. Hence, by the late 19th century little attention was paid to the preservation of railway infrastructure, either mobile (locomotives, train cars) ${ }^{1}$ or permanent, e.g., buildings of the railway station, traffic control infrastructure. Over time decisions were made to take care of the most valuable monuments and first museums were established, which collected and preserved such objects and have turned them into tourist attractions (Kola 2003; Ciechański 2005; Ciechański \& Bebenow 2017). Extensions and reconstructions of railway tracks, stations and technical back offices often destroyed the intentions of the authors of the first railway investment projects in individual locations. Remarkably, in most instances demolition took place to adjust railway areas to the changing user needs and expectations (Peters 2009; Rozema et. al. 2015; Foljanty 2016; Poliński 2016). This is why it is so hard to identify subsequent life cycle stages

1 The first Railway Museum in Europe was opened in 1896 in Hamar, Norway. 
of big railway stations. It is mainly the effect of continuous transformations of railway stations (in particular in the 19th century). Technological progress not only increased train speeds or their allowable length but also transformed technical facilities where locomotives were serviced. The replacement of steam traction with diesel traction followed by almost immediate introduction of electric traction translated into spatial and functional assumptions for railway areas (Kosmowski 2017).

Other determinants of changes and reasons why post-railway areas emerged in central parts of the city should be looked for in natural territorial urban growth (growing ground rent in central, internal parts of the city), but also in economic changes that have led to the closing down of industrial premises in central parts of cities. In European cities dominated with industrial monoculture (e.g., mining or textile industry) changes and economic crises triggered de-industrialisation of entire cities. It echoed in the position of railway transport and sudden collapse in its use to transport semi-finished or finished goods. Such developments were more frequently observed especially in the early 1990s in the cities of Central and Eastern Europe. The above mentioned changes, combined with changes in cargo freight logistics, have made the previously used warehouses obsolete.

Accumulation of these developments in the last two decades of the 20th century significantly reduced the demand for operational railway areas, which triggered their slow degradation. Numerous regeneration interventions in city centres often resulted in the transformation of railway areas (also the oldest locations) even when these were still actively used. Such regeneration schemes covered not only urban fallows (Foljanty 2016). The revitalization of central spaces increasingly fits in the transit-oriented development (TOD), understood as development concentrated around transport nodes (Cervero et al. 2002; Staricco \& Brovarone 2018).

\section{Vienna: overview of spatial growth}

The studies whose results are discussed in this paper focused on parts of central areas of Vienna, one of the oldest urban centres in this part of Europe. Archaeological discoveries in Vienna trace the presence of humans (mainly agricultural tribes) in this part of Europe to 4,000 years ago (Czeike 1992). Urbanisation of territories of contemporary Vienna dates back to Celtic settlements of the 5 th century BC. In the early 1st century the Romans established a military camp for auxiliary troops and then converted it in castrum legionis - Vinodobona (Słodczyk 2012) surrounded with a stone wall that protected them against the invasions of neighbouring tribes (Dzieduszycka 1977) and made part of the Danube fortifications (Gietl et al. 2004). Traces of these ancient settlements can still be seen in the layout of streets in the oldest part of the city (Włoch-Szymla 2010; Sparavign 2017). Subsequent invasions of the German tribes made the Romans leave the castrum in the early 5th century. Over centuries the area of contemporary Vienna (and the city of the Roman times) remained inhabited although the city changed its national affiliation several times as a result of wars.

Henry II Jasomirgott made Vienna the capital city of his newly established duchy (the Duchy of Austria emerged from the Margraviate of Austria) in 1155. His grandson, Leopold VI known as the Glorious, gave Vienna the city rights in 1221 (Czeike 1994). In subsequent centuries the city remained the capital of the Austrian Empire.

Important decisions in the history of Vienna with effects in its spatial growth provided for the construction and demolition of fortifications. In the 12th century city walls were erected in the immediate vicinity of the Old Town (today's district 1: Innere Stadt) using the materials from Roman fortifications. City walls were then modernised until the end of 1857 when first demolitions started on order of Emperor Franz Joseph. Demolition 
decision contained a disposition to delineate and construct a magnificent boulevard RingStrasse encircling the city with stately buildings performing administrative and cultural functions (e.g., Town Hall, Vienna State Opera, Museum of Art History or Natural History Museum).

Fortifications around the Old Town were not the only walls in the 18th and 19th century Vienna. In 1704 Emperor Leopold I made a decision to construct Linienwall - earth embankment with trenches $4 \mathrm{~m}$ high and over $13 \mathrm{~km}$ long situated 2-3 km from the proper city walls. This line of earth fortifications was designed to protect Vienna and its residents against Turks and Kuruc invasions (their scarce remains can still be found in Vienna). Earth embankments were constructed after the fosse had been dug. Fortifications were built in four months as each person residing nearby was obliged to take part in the construction effort. In 1738 fortifications were additionally reinforced with bricks (Blasi \& Sauer 2012). These fortifications further from the central districts of Vienna survived until 1894 although areas south of the Linienwall had been incorporated into the city boundaries 20 years earlier (Hauer 2010). City walls and dense housing stock in between the fortifications were important factors in the construction of railway tracks linking the capital of the Empire with other cities.

\section{Vienna railway}

The first train reached the borders of contemporary Vienna on 23 November 1837 launching the fast growth of railway tracks all over the Austrian Empire (Exner 1929). The first railway connection ran from Vienna to Ostrava (north-east). However, railway station was across the Danube, which at that time was not regulated yet (Hohensinner et al. 2013). The growth of Vienna as a railway centre consisted in developing a network of new railway routes radiating from Vienna and resulted in the construction of 7 termini. There are two important factors behind this situation in Vienna. The first one highlighted by researchers (e.g., Taczanowski 2012) is the multiplicity of investors. In the Austrian Empire, similarly to other European countries, first railway tracks were constructed by target companies which were licensed to build and operate particular routes. The second one, not mentioned in the subject-matter literature is city spatial layout (Fig. 1). As we have mentioned at the beginning of this paper, when first railway connections were constructed in Vienna, the city had two lines of fortifications. Space between them was mostly densely built up. As a result, for economic reasons and because of the need to obtain authorisations to interrupt the continuity of walls and demolish the buildings of the abovementioned seven railway stations, 5 operated outside of the city walls. Twenty two years later the oldest railway station was rebuilt from a terminus into a regular station and railway routes got interconnected.

A railway node including several termini is typical of big cities, important railway centres (e.g., Paris, London). Some cities, e.g., Warsaw in the early 20th century, started reconstructing their railway nodes (building ring and inner railway tracks) to eliminate termini or minimise their negative impact upon the position of a particular city in the railway network of a region or a country. Except building ring and inner railway tracks, modernisation resulted in centrally located railway stations. These have always been huge infrastructural investment projects involving modernisation of other components of urban space. Due to the scope of necessary works, nowadays, the reconstruction of termini into railway stations takes place mainly under regeneration megaprojects (e.g., Łódź Fabryczna or Stuttgart Hauptbahnhof).

\section{Wien Hauptbahnhof: Megaproject in the heart of the City - A city re-invented}

Transformations of parts of the central area of Vienna in the location of Wien Südbahnhof railway station are carried out as a regeneration megaproject "Wien Hauptbahnhof". The 
transformed area covers 109 ha of railway territories incorporated into administrative borders of Vienna in 1850 (almost 10 years after the station had become operational in 1841). For 43 years this part of the 4 th quarter was separated from the oldest part of Vienna with earth-brick fortification line from 1704. The authorities of Vienna acting in consultation with the railway company adopted a Master Plan for the area in 2004. Reconstruction of the Vienna railway node (including the construction of a new central station) strengthened its position as an important transportation centre (national and international) at the north-south and east-west axes (Plank \& Poimer 2017) and part of Austrian Railways Strategy 2025+ (ÖBB-Infrastruktur AG 2011). The website designated for the megaproject was created in 2008 (http:// hauptbahnhof-wien.at - ÖBB-Infrastruktur $A G$ 2008). It provided information on the progress of construction works as well as the links which presented the details of territorial arrangements and the visualisations of the future complex. When the construction was completed, the webpage has been transformed and is now dedicated to the commercial and business activities hosted within the railway station. Among the works devoted to the process of construction the new Wien Hauptbahnohf station, it is worth to mention: Engel (2012), Bönsch (2015), Engel (2016), Lemmerer (2018).

To ensure smooth information flow about the project and progress in its implementation, city authorities appointed a spokesman to the project. Over the time of our studies, the position was held by Hans-Christian Heintschel, who stressed in his statements that the decision to locate the new central railway station in Vienna in the site of Wien Südbahnhof station resulted from analyses of, inter alia, city authorities and railway infrastructure managing company $(\mathrm{QBB})$ conducted in the second half of the 20th century and considering the possibilities to improve railway traffic in Vienna and identify the optimum location for the new Central Railway Station (Urbanowicz 2015b; Winterer 2016). Since the launching of works on the transformation of this part of the Austrian capital, city authorities have been monitoring the project against the scope of its proposed functional programme and planned spatial solutions. Assessment of project implementation and development strategies is an on-going exercise performed by city authorities, which assess the accomplishment of goals and efficiency of introduced solutions. Demolition of existing structures carried out as an intended and planned activity was a valid part of these transformations. Planned demolition may have different scope (Fig. 2); in Viennese megaproject it was applied in some locations as a tool of regeneration enabling the achievement of clearly stated goals of area transformation.

Four out of the above listed dimensions of demolition (in green - Fig. 2): material, spatial (morphological), functional, and economic featuring in the examined regeneration megaproject will be discussed in detail. Three remaining ones (in red): demolition in imagerelated, aesthetical and semiotic dimensions are necessary interventions that need to be carried out to make the area a complementary component of a wider territory after regeneration will have been completed. Moreover, we should stress that elements of demolition in these three dimensions (aesthetical, imagerelated and semiotic) co-exist in all other dimensions.

Material dimension of demolition in Wien Hauptbahnhof megaproject links with the demolition of all objects (such as railway tracks, platforms and buildings) across 109 ha irrespective of their shape. Interested individuals could follow the changes in the area by observing them from especially built observation tower Bahnorame (De), open (Fig. 3) in August 2010 and closed down at the end of 2014 (Maurer 2015) then pulled down in November 2016. It received 350,000 visitors (Urbanowicz 2015b).

An observation deck was placed at the height of $40 \mathrm{~m}$, while the tower was over $66 \mathrm{~m}$ tall (2015). However, we need to stress that first demolition works took place already in 2007. 


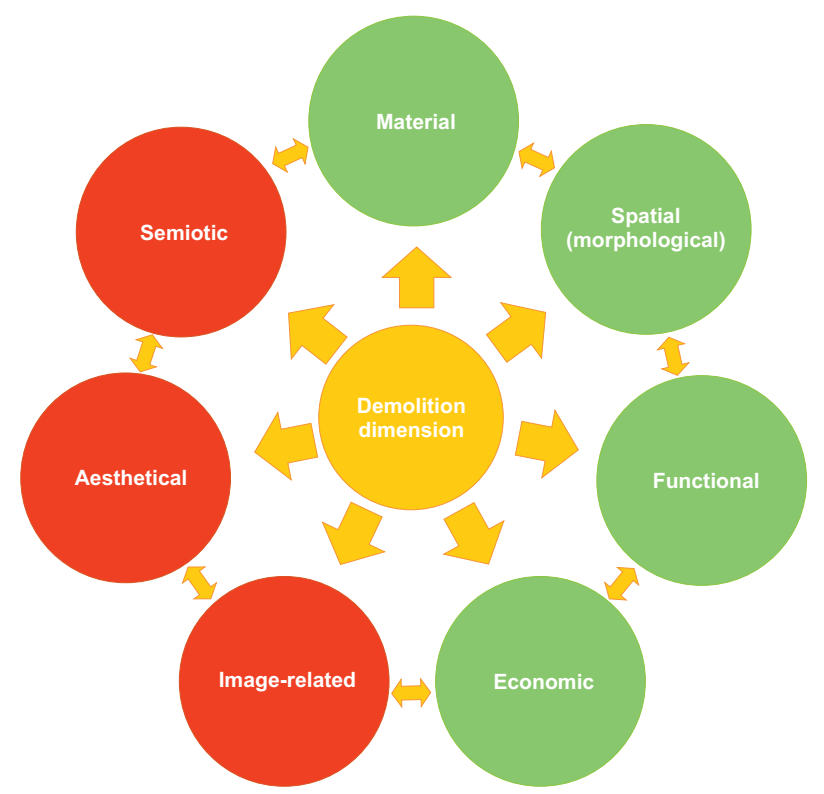

Figure 2. Dimensions of demolition in Wien Hbf Project

Although railway transport function was maintained in the area covered by the project, all the existing structures were demolished. The goal was to provide top notch and state-of-the-art railway infrastructure, which would not be achieved by simply modernising the earlier solutions. This approach helped design a completely new spatial and functional area covered by the project in the carte blanche approach. Interventions intended to clear the area for the designed Wien Hauptbahnhof station of any structures were carried out leaving the railway traffic undisturbed throughout the entire project. Works on the new railway track layout were carried out on the side of district 10 towards district No. 4. Transformations were implemented in stages:

- temporary terminus constructed in the vicinity of Vienna Arsenal,

- pulling down buildings, dismantling railway tracks and auxiliary infrastructure, starting with sidings (on the side of Sonnwendgasse and Gudrunstraße),

- soil remediation,
- levelling the area using debris from pulled down buildings,

- building a school and residential buildings in former rail sidings,

- construction of a railway station and office buildings on the south,

- construction of office buildings on the former square in front of the railway station.

It called for orchestrated cooperation of designers and executors with railway infrastructure manager responsible for the safety of railway traffic almost in the middle of the construction site, as well as with municipal services and new (mostly) private investors (constructing residential and office buildings).

There were two aspects to spatial dimension of demolition. The first was the liquidation of the earlier spatial layout, the outcome of constructing the railway station the closest to the Linienwall and delineating railway tracks alongside fortifications (westwards and southwards). Constant unchanged spots included contacts with left railway tracks "at project extreme ends" (T1 and T2 in Fig. 4), railway track crossings in the same place at two levels in Südtiroler Platze and 


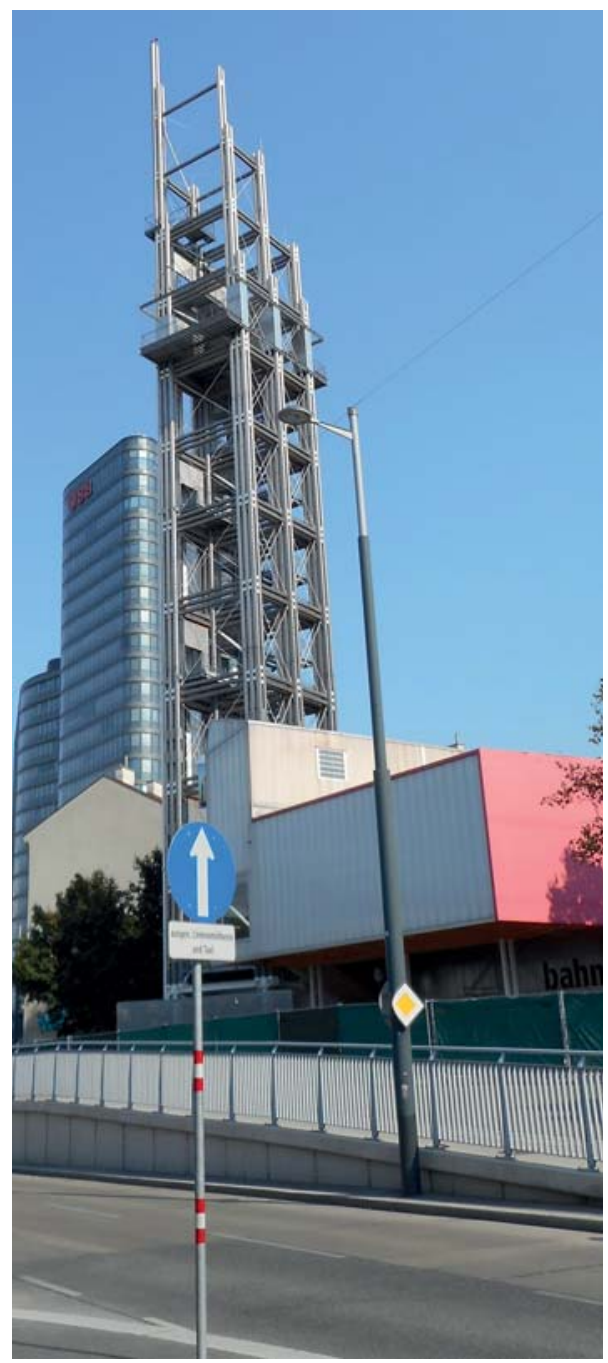

underground station U1 Südtiroler Platz - Hauptbahnhof and a tramway tunnel - S (Fig. 4). Additionally two other railway crossings have been left (also at two levels - track bridges over the streets): one in Matzleinsdorfer Platz $(M)$ and the other one at the extension of Landgutgasse (L).

Before regeneration the area (as a result of its history) acted as a uniform barrier in space playing the role identical to that of the earlier Linienwall fortifications. Similarly to the latter, which had only some 'gates' where walls could be crossed, also the tracks placed over the street level are cut by several streets. Before reconstruction, alongside the zone (ca. $4.5 \mathrm{~km}$ - Fig. 5) railway tracks could be crossed in five places (marked as $M, L, S$, $T 1, T 2$ ) plus using the underground beneath at the height of $S$. Currently, after the regeneration pedestrians have got further 4 possibilities (all of them in the vicinity of the railway station) of crossing the railway tracks. Two additional crossings are under construction (yellow lines on Fig. 4). Such space organisation has removed the barrier posed by the railway tracks. The length of railway track from T1 to T2 is $4.58 \mathrm{~km}$.

Before the project has started, average distance between railroad pedestrian crossings was $1.15 \mathrm{~km}$. In the course of field studies (2015) it got reduced to $0.57 \mathrm{~km}$ with the target distance of $0.49 \mathrm{~km}$ (Fig. 5). An attempt was made to minimise the barrier effect, i.e., the division resulting from leaving railway

Figure 3. Bahnorame, August 2015

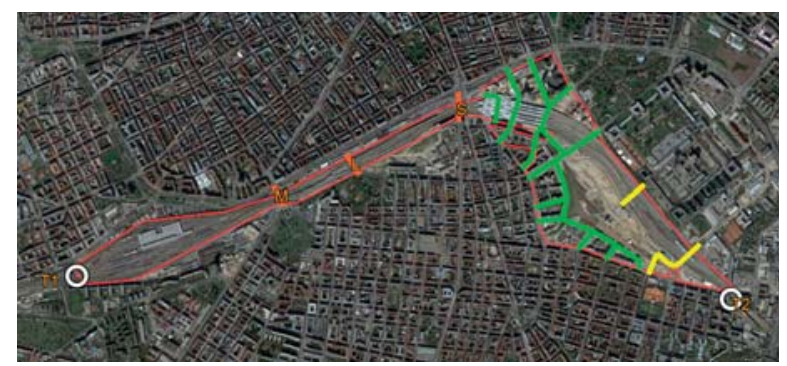

Figure 4. Railway tracks crossings before and after the project with new streets network

Source for base map: Google Earth. 


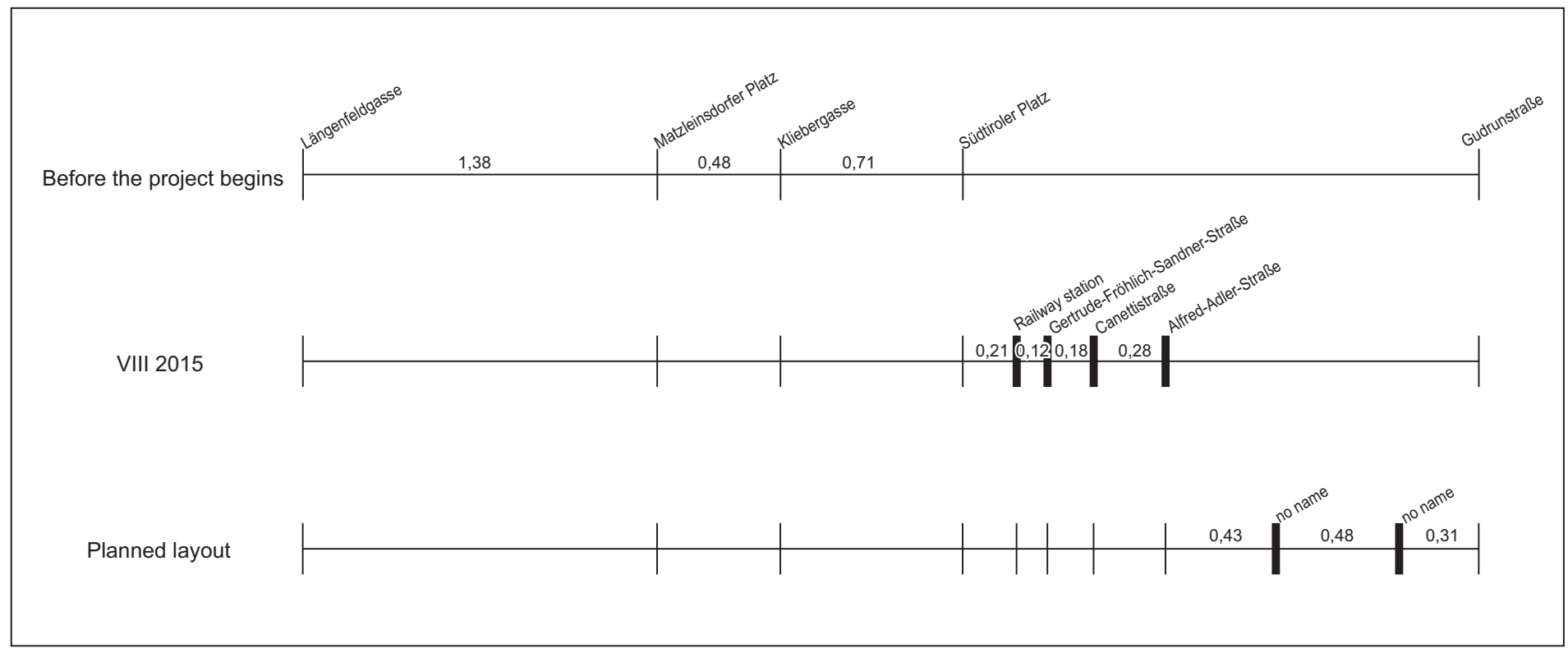

Figure 5. Distances between railroad crossings 
tracks over the ground level. Barrier effect caused by railway tracks running across the city has been described by, e.g., Wesołowski (2002). He argues that railroads elevated above the ground level create bigger barriers than railway tracks in trenches or tunnels but smaller than level railroads. Considering the location of the transformed area within the city at the contact point of four districts, intensification of links among them is expected as a result of enhanced traffic (not only pedestrian). Changes to pedestrian users of this area will become even more clear when time-based analysis of the accessibility of areas from the entrance into the station will be performed (Fig. 6).

Before the megaproject has been implemented, 15-minute walking range covered an area by 29\% smaller than in 2015 (1.27 km² in 2008 and $1.78 \mathrm{~km}^{2}$ in 2015). Target plans assume that after the area alongside the park will have been developed, within 15 minutes the area of $1.85 \mathrm{~km}^{2}$ will be accessible. As a result, the railway station will 'open' itself to district 10 (Favoriten) and to newly developed post-railway areas. It will impact the way this area operates as a meeting place of districts 3, 4, 5, and 10 .

Spatial accessibility of the railway station needs to be looked at not just from the ground level but also vertically. In the case of Wien Hauptbahnhof railway station care was taken to connect it with underground station of the U1 line. To reduce distances to be covered by passengers between the underground station and the railway station an underground passage was provided and travellers and commuters have only $340 \mathrm{~m}$ to walk between the platforms of both stations. It is feasible since the railway station was moved by ca. $200 \mathrm{~m}$ westwards. The new arrangement has enriched the area with crucial urban facilities and better access to transport (Glaeser et al. 2001), which surely impacts residents' quality of life (Sokołowicz 2017).

Demolition of parts of railway areas across the project included the dismantling of railway tracks and building them anew. It was caused by the new layout of tracks and shifting ca. $100 \mathrm{~km}$ of tracks to a new location (Taczanowski 2012) and local changes in their altitude. The old square in front of the old buildings of the railway station was designated to host service functions (offices, stores, and hotels) in four new quarters. The area was called Quartier Belvedere after the nearby Baroque palace. In south-east part of the Wien Hauptbahnhof megaproject new quarters were earmarked for residential buildings. Streets at the borders of new quarters in this part of the megaproject are extensions of already existing streets and the new layout supplements the earlier spatial structure. Behind the first of residential buildings a new linear park (Helmut-Zilk-Park) was planned with tram line ("D"), which will be extended in the second stage by ca. $1.5 \mathrm{~km}$ (terminal stop south of the railway station became operational together with the new railway station) with service and industrial structures (next to the railway tracks).

Functional dimension of demolishing connects with the shaking of the practically 'monocultural' use of this part of Vienna. Functional plans identified priorities which guided the authorities of Vienna. The target plan is to build 5,500 new apartments, mostly by private developers. The planned functional layout of the area covered by the megaproject is shown in Figure 7.

Functional dimension of demolishing was also supposed to include this area of the city into the network of municipal transport. Stage-wise extension of tram line " $D$ " offers more convenient solutions not only to passengers travelling from/to Vienna's Main Railway Station (tram stop located directly under the platforms) but also to new local residents. The construction of educational establishments (e.g., a primary school for over 1,000 children) minimises the need to drive children to school. New functional layout reduces the environmental (noise) impact of railways. Earlier railway areas in the north and in the south bordered residential areas while after regeneration, wherever possible, they will neighbour service and industrial structures. New functions emerged mainly in the 


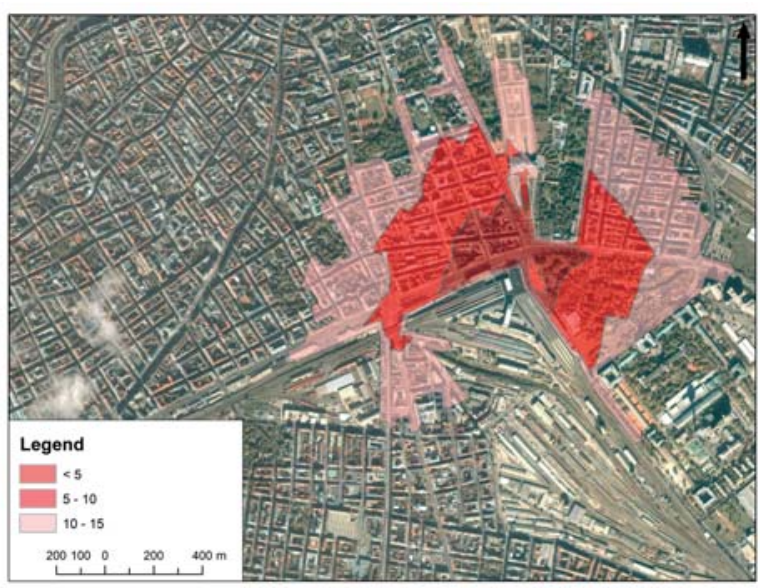

Piotr Kosmowski
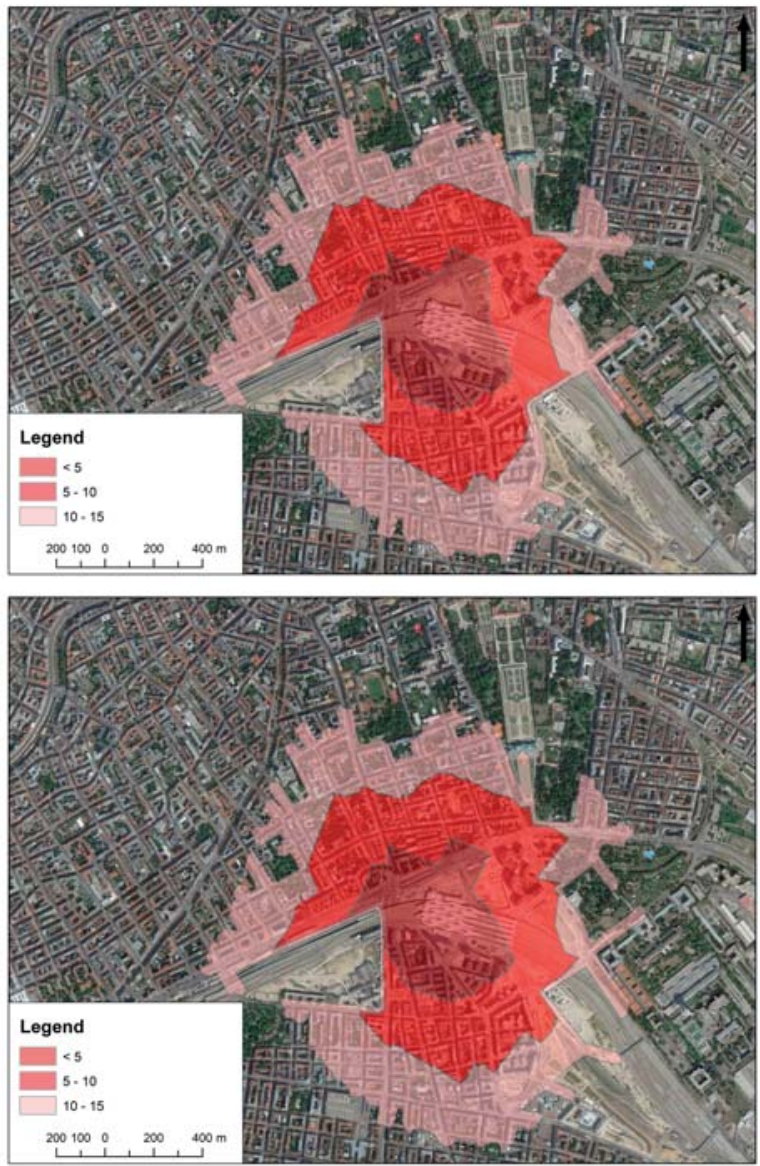

Figure 6. 5-10-15-minute walking access to entrances into the station before the megaproject were implemented, the range during field studies, August 2015, and target range ${ }^{\star}$

Source: author's own compilation based on the ArcGis software, base map - Google Earth.

* Average speed with which a pedestrian moves is assumed to be $4 \mathrm{~km} \cdot \mathrm{h}^{-1}$. Analysed network included all pavements available in a given year. To build the model of pavement network within the planned scope, we used road layout plans. 


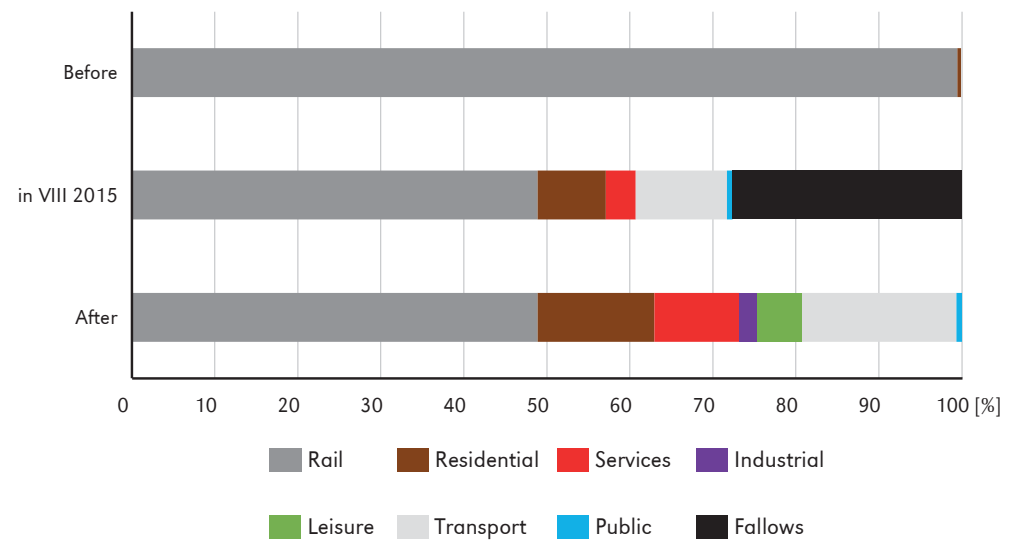

Figure 7. Functional use of area covered by the project

vicinity of the railway station - the place with the highest intensity of railway-related noise (Wszołek \& Koter 2015).

Demolition at economic level is the outcome of changes in the structure of jobs within the area covered with the examination. According to the assumptions, in the area covered by the megaproject we should expect ca. 20,000 new jobs (Urbanowicz 2015b). Obviously, not all local residents will work within this area but such functional pattern impedes the urban sprawl and moving jobs outside of the city centre. According to the assumptions predicted in the project, approximately 30,000 people will live and work on the transformed area (ÖBB-Infrastruktur AG 2018).

\section{Conclusions}

Our considerations were designed to describe and assess demolition taking place at different levels in areas of Vienna covered by the regeneration megaproject aimed at the reconstruction of a terminus into a regular railway station. Results of our studies helped us identify stages of demolition, its scope and typical attributes, as well as to highlight morphological and functional changes involved.

Discussed in detail aspects of demolition (material, spatial, functional, and economic) intentionally deployed in city renewal enabled effective and rapid implementation of new spatial (morphological) and functional structure of the area. We need to bear in mind that demolition discussed in the paper linked with multidimensional destruction does not have to (or even does not) entail negative connotations. It is a choice of rational course of events which facilitates precise implementation of planned goals.

The selection of demolition as a tool of regeneration in the Wien Hauptbahnhof megaproject was dictated by the intention to renew the area using innovative practical solutions. Building part of the city anew not only improved the functionality of the new railway station but also permanently linked the area with its neighbourhood. As stressed by Szmytkowska (2016: 12) "creating a contemporary city consists not only in achieving its functional effectiveness but also in sustainable dialogue in shared urban space." Demolition as a tool makes it happen only when the entire process is well planned and implemented in accordance with the assumptions of the megaproject at multiple levels, taking account of activities undertaken by a series of public and private partners. Assumptions adopted for this area highlighted in the case of transformation of Vienna double terminus into the main railway station of the Austrian capital reveal the potential of railway and post-railway areas in European cities and the 
complexity of their regeneration. We need to stress that the investigated case of using a radical tool such as multidimensional demolition in regeneration of railway areas in inner cities shows that its application produces beneficial changes in space organisation.

\section{Acknowledgements}

This paper is financed by National Science Centre of Poland based on decision no. DEC2014/15/B/HS4/01940.

\section{References}

AHLFELDT G., 2012. Rail mega-projects in the realm of inter-and intra-city accessibility: Evidence and outlooks for Berlin. Built Environment, vol. 38 no. 1, pp. 71-88.

Blasi W., Sauer F., 2012. Die Kuruzzenschanze zwischen Petronell und Neusiedl am See. Materialheft Reihe A, Sonderheft 19, Fundberichte aus Österreich, Vienna: Berger.

BöNsCH R. (ed.), 2015. Hauptbahnhof Wien: Die Veränderung eines Stadtteils 2009-2014. Basel: Birkhäuser.

CARMON N., 1999. Three generation of urban renewal policies: Analysis and policy implications. Geoforum, vol. 30, no. 2, pp. 145-158.

Cervero R., Ferrell C., Murphy S., 2002. Transitoriented development and joint development in the United States: A literature review. Transit Cooperative Research Program. Research results digest, no. 52, Washington, D.C.: Transportation Research Board.

CIECHAŃSKI A., 2005. Zagospodarowanie turystyczne obiektów kolejowych jako forma ochrony dziedzictwa kultury technicznej. Prace Komisji Geografii Komunikacji PTG, vol. 11, pp. 81-104.

Ciechański A., Bebenow F., 2017. Turystyka oparta na dziedzictwie kulturowym kolei - czy bariery formalne i finansowe skutecznie blokuja jej rozwój? TTS Technika Transportu Szynowego, vol. 24, no. 7-8, pp. 46-54.
Editors' note:

Unless otherwise stated, the sources of tables and figures are the authors', on the basis of their own research.

CZzike F., 1992. Historisches Lexikon Wien in 5 Bänden. Bd. 1, [A - Da]. Wien: Verlag Kremayr \& Scheriau.

Czeike F., 1994. Historisches Lexikon Wien in 5 Bänden. Bd. 3, [Ha-La]. Wien: Verlag Kremayr \& Scheriau.

DzieDUSZYCKA B., 1977. Ze studiów nad wczesnośredniowiecznymi technikami budownictwa obronnego. Umocnienia wczesnośredniowiecznego Kaszowa w województwie wrocławskim. Slavia Antiqua, vol. 24, pp. 73-118.

ENGEL J., 2012. Wien Hauptbahnhof - Mehr als ein Bahnhof. Beton-und Stahlbetonbau, vol. 107, no. 6, pp. 421-428.

Engel J., 2016. Wien Hauptbahnhof - Wie Bürgerbeteiligung Planung und Bau eines Großprojekts begleiten kann [in:] M. Glaab (ed.), Politik mit Bürgern - Politik für Bürger, Bürgergesellschaft und Demokratie, Wiesbaden: Springer VS, pp. 239-256.

EXNER W., 1929. Erlebnisse. Berlin, Heidelberg: Springer.

FlYVBJerg B., 2014. What you should know about megaprojects and why: An overview. Project Management Journal, vol. 45, no. 2, pp. 6-19.

FoluANTY K., 2016. Przekształcanie zabytkowych dworców i terenów kolejowych w struktury wielofunkcyjne. Architectus, vol. 46, no. 2, pp. 65-78.

Gietl R., Kronberger M., Mosser, M., 2004. Rekonstruktion des antiken Geländes in der Wiener Innenstadt. Fundort Wien, Bd. 7, pp. 32-53. 
Glaeser E.L., Kolko J., Saiz A., 2001. Consumer city. Journal of Economic Geography, vol. 1, no. 1, pp. 27-50.

Hamnett C., Shoval N., 2003. Museums as flagships of urban development [in:] L. Hoffman, Fainstein S., Judd D. (eds.), Cities and visitors: Regulating people, markets and city space, Oxford: Blackwell, pp. 219-236.

HaUer F., 2010. Die Verzehrungssteuer 1829-1913 als Grundlage einer umwelthistorischen Untersuchung des Metabolismus der Stadt Wien. Social Ecology Working Paper, 129, Vienna: Institute of Social Ecology, IFF - Faculty for Interdisciplinary Studies (Klagenfurt, Graz, Vienna), Alpen Adria Universitaet.

Hohensinner S., Lager B., SonnleChner C., Haidvogl G., Gierlinger S., SChmid M., Krausmann F., WINIWARTER V., 2013. Changes in water and land: The reconstructed Viennese riverscape from 1500 to the present. Water History, vol. 5, no. 2, pp. 145-172.

KaCZMAREKS., 2001. Rewitalizacja terenów poprzemysłowych. Nowy wymiar $w$ rozwoju miast. Łódź: Wydawnictwo Uniwersytetu Łódzkiego.

KACZMAREK S., 2015. Skuteczność procesu rewitalizacji. Uwarunkowania, mierniki, perspektywy. Studia Miejskie, vol. 17, pp. 27-36.

Kaczmarek S., 2017. Demolowanie jako radykalne narzędzie $w$ procesie rewitalizacji. Studia Miejskie, vol. 28, pp. 9-20.

Kola R., 2003. Zabytkowy krajobraz obszarów komunikacji kolejowej. Z zagadnień ochrony i konserwacji. Ochrona Zabytków, vol. 1-2, pp. 182-201.

KosmOWSKI P., 2017. Rewitalizacja miejskich terenów pokolejowych. Przykład Lipska. Studia Miejskie, vol. 28, pp. 87-98.

KostrzeWski M., 2014. Development of the postrailroad lands - Solutions background in the world. Logistyka, vol. 4, pp. 4496-4501.

LeMmerer D., 2018. Rationalisierungsweisen sozialraumbezogener Ansätze im Kontext unternehmerischer Stadtpolitik. Sozialraumarbeit im Stadtentwicklungsgebiet Hauptbahnhof Wien. soziales_kapital, vol. 19, pp. 17-31.

LORENS P., 2006. Wielkoskalarne przedsięwzięcia urbanistyczne jako element strategii przekształceń miast: przypadek terenów przydworcowych [in:] D. Załuski (ed.), Dworzec kolejowy w strukturze miasta, Biblioteka Urbanisty, no. 8, Warszawa: Urbanista, pp. 60-66.

LORENS P., 2010. Rewitalizacja miast: planowanie i realizacja. Gdańsk: Wydział Architektury Politechniki Gdańskiej.

MaURer A., 2015. Wer will mich?. http://www. wienerzeitung.at/nachrichten/wien/stadtpolitik/765057_Wer-will-mich.html [15 February 2018].

Novy J., Peters D., 2012. Railway station megaprojects as public controversies: The case of Stuttgart 21. Built Environment, vol. 38, no. 1, pp. 128-145.

ÖBB-INFRASTRUKTUR AG, 2008. Wien Hauptbahnhof. http://hauptbahnhof-wien.at/ [21 July 2015].

ÖBB-InFRASTRUKTUR AG, 2011. Zielnetz 2025+. https://infrastruktur.oebb.at/de/unternehmen/fuer-oesterreich/zukunft-bahn-zielnetz/ Zielnetz_2025\%2B_Downloads_?datei=Ziel netz+2025+Ergebnisbericht.pdf [10 February 2018].

ÖBB-INFRASTRUKTUR AG, 2018. Wien Hauptbahnhof. http://wien-hauptbahnhof.oebb.at/ [10 August 2018].

ORUETA F.D., FaInSTEIN S.S., 2008. The new mega-projects: Genesis and impacts. International Journal of Urban and Regional Research, vol. 32, no. 4, pp. 759-767.

PARYSEK J.J., 2015. Rewitalizacja jako problem i zadanie własne polskich samorzadów lokalnych. Rozwój Regionalny i Polityka Regionalna, no. 33, pp. 17-35.

Peters D., 2009. The renaissance of inner-city rail station areas: a key element in contemporary urban restructuring dynamics. Critical Planning, 16, pp. 163-185.

Plan V., Poimer B., 2017. The significance of the southern line on an European, national and regional scale - The strengthening of the corridor in the ÖBB target network 2025+ and beyond. Geomechanics and Tunnelling, vol. 10, no. 6, pp. 651-659.

PolINSKI J., 2016. Dworce we współczesnym transporcie kolejowym. Prace Instytutu Kolejnictwa, no. 150 , pp. $51-58$.

Rozema J.G., Cashmore M., Bond A.J., Chilvers J., 2015. Respatialization and local protest strategy formation: Investigating high-speed rail 
megaproject development in the UK. Geoforum, vol. 59, pp. 98-108.

SŁOdCZYK J., 2012. Historia planowania i budowy miast. Opole: Wydawnictwo Uniwersytetu Opolskiego.

SoKoŁowicz M., 2017. Udogodnienia miejskie element publicznego wymiaru zasobów mieszkaniowych. Acta Universitatis Lodziensis. Folia Oeconomica, vol 6. no. 332, pp. 125-143.

Sparavigna A.C., 2017. Wien and the Winter Solstice. Available at SSRN: https://ssrn.com/abstract=2899730 [DOI: 10.2139/ssrn.2899730] [3 February 2018].

Staricco L., Brovarone E.V., 2018. Promoting TOD through regional planning. A comparative analysis of two European approaches. Journal of Transport Geography, vol. 66, pp. 45-52.

SzMYTKOWSKA M., 2016. Realizacje urbanistyczne $w$ mieście postindustrialnym $i$ ich wpływ na kształtowanie ładu przestrzennego. Studia Miejskie, vol. 22, pp. 9-22.

TACZANOWSKI J., 2012. Stacja Wien Hauptbahnhof jako czynnik rozwoju przestrzennego i funkcjonalnego Wiednia. Studia Miejskie, vol. 5, pp. 33-45.

TRIP J.J., 2008. Urban quality in high-speed train station area redevelopment: The cases of Amsterdam Zuidas and Rotterdam Centraal.
Planning, Practice \& Research, vol. 23, no. 3, pp. 383-401.

Urbanowicz W., 2015a. Wiedeń daje przykład, jak wpisać dworzec w miasto. http://www.transport-publiczny.pl/wiadomosci/wieden-daje-przyklad-jak-wpisac-dworzec-w-miasto-49889. html [19 February 2018].

Urbanowicz W., 2015b. Nowy Wiedeń Gtówny: Jak tory zamienity się w nowoczesna dzielnicę, http://www.transport-publiczny.pl/wiadomosci/ nowy-wieden-glowny-jak-tory-zamienily-sie-wnowoczesna-dzielnice-50350.html [17 February 2018].

WESOŁOWSKI J., 2002. Dworzec elementem miejskiego continuum. TTS Technika Transportu Szynowego, vol. 9, no. 7-8, pp. 22-31.

Winterer M., 2016. Neu gebaute Tristesse. Wiener Zeitung, http://www.wienerzeitung.at/ nachrichten/top_news/816806_Neu-gebauteTristesse.html [5 February 2018].

WŁoch-SzYmLA A., 2010. Kształtowanie się przestrzeni publicznej $w$ miejskim środowisku zamieszkania - Wiedeń. Czasopismo Techniczne, vol. 107, no. 6, pp. 301-309.

Wszołek T., Koter M., 2015. Parametryzacja i ocena hałasu pisków od krzywizn i hamowania podczas dojazdu pociagu do stacji. Przegląd Mechaniczny, no. 7-8, pp. 38-42.
(C) Piotr Kosmowski
Article first received • March 2018 Article accepted • October 2018 